\title{
SPATIAL FUNCTIONAL TRANSFORMATION AND TYPOLOGY OF THE SETTLEMENT SYSTEM OF TOPLICA DISTRICT
}

\author{
JOVAN DRAGOJLOVIĆ ${ }^{1}$, DUŠAN RISTIĆ ${ }^{2}$, NIKOLA MILENTIJEVIĆ ${ }^{1}$ \\ ${ }^{1}$ Faculty of Sciences and Mathematics, University of Priština, Kosovska Mitrovica, Serbia \\ ${ }^{2}$ Fakulty of Geography, University of Belgrade, Belgrade, Serbia
}

\begin{abstract}
Contemporary processes of industralization, urbanization, deagrarianization, the polarization and globalization contribute socio-economic transformation of the observed space as well as the creation of new carrier of functional relationships in space. Towns with its own influences enrich the network of surrounding settlements, strengthen their mutual relations and create a whole functional settlement system of one area, or the gravity of the urban core. By dividing the functions of the primary, secondary and tertiary, the basis and types of settlements are created by functional criteria according to the type of economic activity and the primary content in them. In this area in the second half of the twentieth and early twenty-first century witnessed substantial changes in almost all components of demographic structure, which resulted in the transformation of functional types of settlement, when the predominantly agrarian settlement characteristic of the area of Toplica road went up mixed and service settlement. The idea behind the study is for the geographically complex area to be displayed in the light of socioeconomic development, and as a basis for further economic development of this part of the Republic of Serbia.
\end{abstract}

Keyword: urbanization, rural settlements, urban settlements, functions, typology, sustainable development, District of Toplica

\section{INTRODUCTION}

Toplica district is located in the southern part of the Republic of Serbia and occupies a historical and geographic area, known as Toplica. Its northern border is Rasina district, Nišava district in the east, in southeast is Jablanica, and in the south Kosovo district. Toplica is a region which in the physicalgeographical terms belongs to the depression-mountain-valley macro-region, or mezoregions of South Serbia.

The region is limited to the east by South Morava, a western border region bounded Kopaonik. The northern border region is represented by parts of the Great and Small Jastrebac, while the southern border connecting the corners of the highest parts of the Maidan, Djak, Radan, Petrovac, Bucumetski height, Greben and Dobre Glave.

If administrative regionalization was observed, Toplica region would be limited by the Toplica district, which consists of four municipalities: Prokuplje, Kuršumlija, Blace and Žitoradja. The District has a total of 90,600 inhabitants according to the census of 2012, while 2002 had 111,813 inhabitants. Population density is 40.61 inhabitants / $\mathrm{km}^{2}$, which is below the national average. Its seat is a town Prokuplje. Borders of Toplica districts do not coincide with the natural, physical and geographical boundaries of the region and therefore county, as well as administrative spatial unit occupies only $73 \%$ of the region of Toplica, or an area of $2231 \mathrm{~km}^{2}$ (Rudić, 1978).

The largest territorial unit by area is Kuršumlija municipality $952 \mathrm{~km}^{2}$ (42.7\% of Toplica region), then Prokuplje

\footnotetext{
* Corresponding author: jovan.dragojlovic@pr.ac.rs GEOGRAPHY
}

municipality with an area of $759 \mathrm{~km}^{2}$ (34.0\%), Blace municipality has an area of $306 \mathrm{~km}^{2}(13.7 \%)$, and lowest per surface is the territory of the municipality of Žitoradja $214 \mathrm{~km}^{2}$ $(9.6 \%)$.

\section{MATERIAL AND METHODS}

Significant contribution to the functional systematization of the settlements was given by (Grčić, 1999), who elaborated the methodology of the typological classification of the settlements. The concept of the economic structure of the population was applied in this work to determine the functional type of settlement of Toplica district, which is determined based on the structure of the active population according to activities, in other words, it is based on principle of dominant activity (functions). Apart from the structure of the active population the functional determination of the settlements regulates the overall activity with regards to the geographic position and socio-ecological conditions (Christaller, 1933). The method of tenar diagram is applied in this work, as one of grafical method of allocation of the functional type of settlements. It was presented by equilateral triangle whose sides are divided into sections that indicate the percentages of primary, secondary and tertiary activity.In order to fulfill the condition of participation of the active population by sectors up to $100 \%$, in tertiary activities, a group of quaternary is included (health, education, information, local government). The interior of the diagram is divided into types, indicated by a conbination of numbers and latters. The functional type will be defined in the intersection of three lines each of which has the value of a particular sector of activity (Matijević, 2009). Based on the economic composition of the population according to the 
sectors of activity, functional types of settlements and their subtypes are distinquished (Myrdal, 1957).

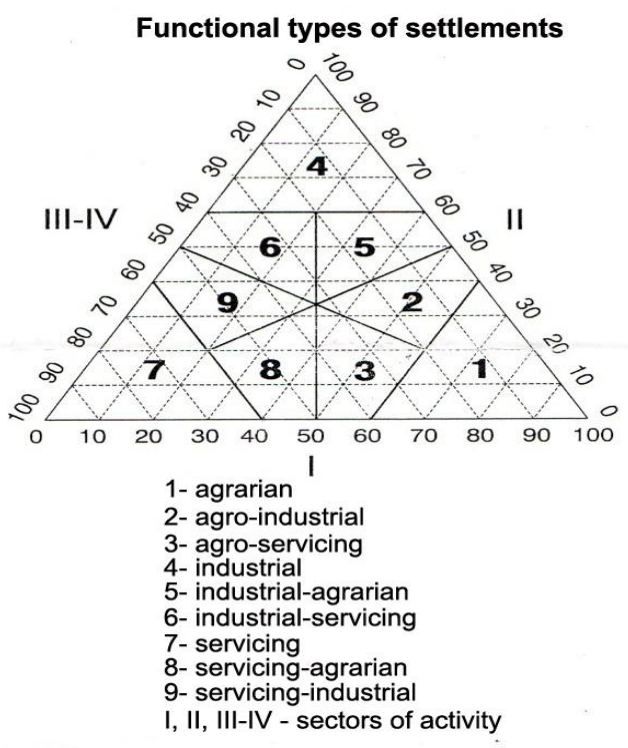

Figure 1. Application of Horst-Fere triangle to determine the functional type of settlement. Source: handout "Types of population movements"

Geographical, traffic and administrative situation of the settlements affect the functional typology of the settlement, while the basic features are largely determined by population movements (Boudeville, 1966). The structure of population activities is an indicator that is used to determine the spatial and functional relationships that affect the transformation of the settlements (Vresk, 1990).

Method of Horst-Fere triangle (Fig. 1) involves separation of the nine types of settlements based on the participation of individual sectors of activity in the contingent of the population performing occupation. The method is adapted to our circumstances, and the available data. Figure 2. shows the tenar diagram for all four municipalities of Toplica district.

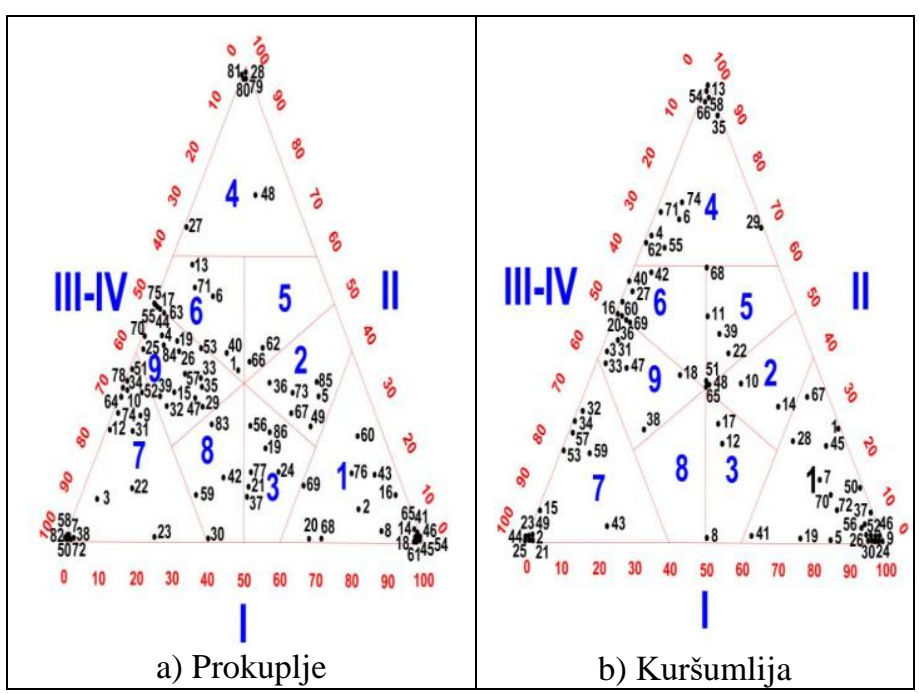

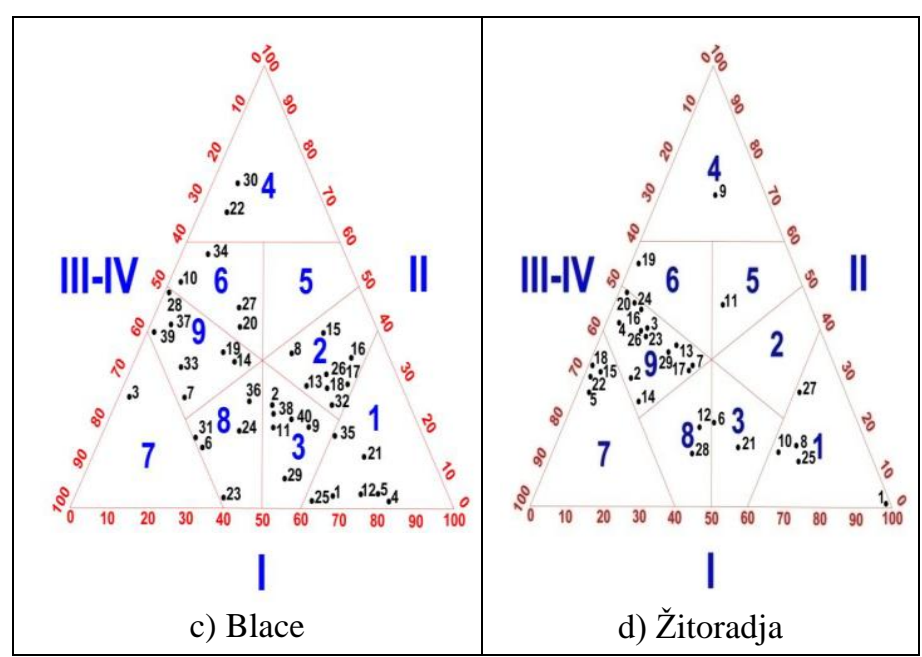

Figure 2. Horst-Fere's settlements triangle (a,b,c,d) municipalities of Toplica District.

The functional type of settlement is determined on the basis of the share of primary, secondary and tertiary sector activity in the total population performing occupation (Davies, 1967). The threshold for determining dominant belonging to a certain sector of activity is $60 \%$ (Table 1 ).

In Table 1, marked with Roman numerals, are sectors of activity: I - primary (agricultural) sector II - secondary (industrial) sector and III - tertiary-quaternary (service) sector.

Table 1. Model for extracting functional types of settlements.

\begin{tabular}{|l|l|}
\hline Functional type of settlements & Criteria \\
\hline Agrarian & I $\geq 60 \%$ \\
\hline Agro-industrial & I $>$ II $>$ III \\
\hline Agro-service & I $>$ III $>$ II \\
\hline Indusrtial & II $\geq 60 \%$ \\
\hline Industrial-agrarian & II $>$ I $>$ III \\
\hline Industian-service & II $>$ III $>$ I \\
\hline Service & III $\geq 60 \%$ \\
\hline Service-agrarian & III $>$ I $>$ II \\
\hline Service-industrial & III $>$ II $>$ I \\
\hline
\end{tabular}

Source: Tošić, D. (2012): Principles of regionalization. Belgrade. University of Belgrade - Faculty of Geography.

\section{RESEARCH RESULTS AND DISCUSSION}

The process of industrialization in Serbia started in the period between the two world wars, to its full momentum experienced in the years after World War II, mostly during the $60 \mathrm{~s}$ and $70 \mathrm{~s}$ of the twentieth century. (Stamenković, Bačević, 1992). Industrialization was the trigger for intensive deagrarization and urbanization of our premises or relocation of the working age population from rural to urban areas, which have become industrial centers (Green, 2004). Although the process of industrialization greatly slowed to such an extent that 
one can speak of deindustrialisation, agrarian reform and urbanization processes are still ongoing. The population continues to leave the rural areas and moved to urban and suburban areas. The same situation exists in the administrative district of Toplica, except that the demographic base is pretty empty, which means that there are fewer people in rural areas, which could be moved to urban areas.

Table 2. The number of settlements by functional types of settlements.

\begin{tabular}{|c|c|c|c|c|c|c|c|c|c|c|c|c|c|c|c|}
\hline \multirow{3}{*}{ Type } & \multicolumn{12}{|c|}{ Municipality 1981, 2002. and 2011. Year } & \multirow{2}{*}{\multicolumn{3}{|c|}{ Total }} \\
\hline & \multicolumn{3}{|c|}{ Žitorađa } & \multicolumn{3}{|c|}{ Prokuplje } & \multicolumn{3}{|c|}{ Blace } & \multicolumn{3}{|c|}{ Kuršumlija } & & & \\
\hline & 81 & 02 & 11 & 81 & 02 & 11 & 81 & $\mathbf{0 2}$ & 11 & 81 & 02 & 11 & 81 & 02 & 11 \\
\hline A & 29 & 7 & 5 & 105 & 59 & 17 & 39 & 15 & 6 & 84 & 48 & 22 & 257 & 129 & 50 \\
\hline AI & 0 & 3 & 0 & 1 & 10 & 5 & 0 & 13 & 8 & 1 & 8 & 6 & 2 & 34 & 19 \\
\hline AS & 0 & 6 & 2 & 0 & 8 & 9 & 0 & 4 & 8 & 3 & 6 & 4 & 3 & 24 & 23 \\
\hline I & 0 & 1 & 1 & 0 & 4 & 6 & 0 & 0 & 2 & 2 & 1 & 12 & 2 & 5 & 21 \\
\hline IA & 0 & 3 & 1 & 0 & 5 & 1 & 0 & 2 & 0 & 0 & 4 & 3 & 0 & 14 & 5 \\
\hline IS & 0 & 4 & 1 & 1 & 10 & 5 & 1 & 4 & 3 & 0 & 6 & 4 & 2 & 24 & 13 \\
\hline $\mathrm{S}$ & 0 & 0 & 4 & 0 & 2 & 19 & 0 & 0 & 1 & 0 & 7 & 13 & 0 & 9 & 37 \\
\hline SA & 0 & 2 & 2 & 0 & 3 & 4 & 0 & 0 & 4 & 0 & 3 & 1 & 0 & 8 & 11 \\
\hline SI & 1 & 4 & 13 & 0 & 5 & 20 & 0 & 2 & 8 & 0 & 3 & 9 & 1 & 14 & 50 \\
\hline W & 0 & 0 & 1 & 0 & 1 & 21 & 0 & 0 & 0 & 0 & 4 & 17 & 0 & 6 & 38 \\
\hline
\end{tabular}

Source: National Bureau of Statistics

Functional types of settlements Toplica were analyzed during 1981, 2002. and 2011. (Table 2). Settlements of Toplica region in 1981 were predominantly agrarian. Even 257 from 267 settlements $(96 \%)$ were distinctly agrarian functional type, which means that over $60 \%$ of the population engaged in its activities in the primary sector.Out of ten remaining settlements, five were the most common agrarian sector: two agrarian-industrial Gelding (Kuršumlija municipality) and Mala Plana (municipality of Prokuplje) and three agro-service - Kuršumlijska Banja, Barlovo and Merćez (all in the municipality of Kuršumlija). (Spatial Plan of the Municipality of Kuršumlija).

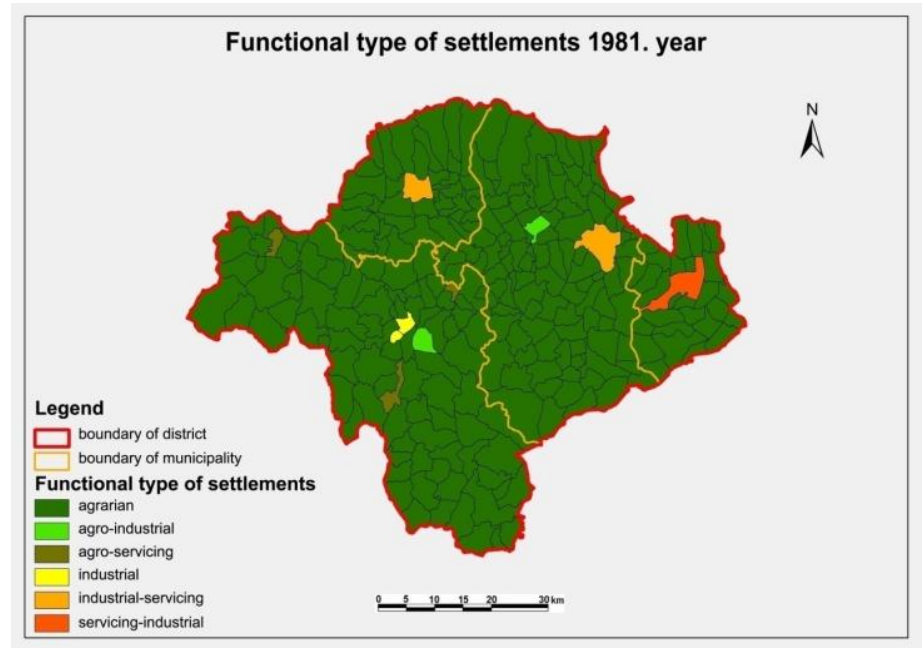

Figure 3. Functional type of settlement in 1981. (Federal Statistical Yugoslavia, 1984).
Two settlements were an industrial functional type: Kuršumlija municipal center and its suburb Markoviće. Two settlements of industrial-service-municipal are centers of Blace and Prokuplje, while the only village with a dominant service function, and service-industrial type was the easternest and lowest municipal center - Žitoradja (Spatial Plan of the Municipality of Prokuplje).

On the chart of the functional type of settlements in 1981 (Fig. 3) is notable that the scarce settlements that do not belong to the agrarian type distributed around the municipal centers, or at major traffic routes (Spatial plan of the Municipality of Blace).

In the 21-year period from 1981. to 2002. there have been significant changes in the functions of the Toplica settlement. The process of diversification of the economy is set and nonagricultural activities began to spread outside the municipal centers. Originally, it was industry, which was responsible for the development of this region, but it also increased the share of service sector activity (Dragojlović, 2017).

The largest number of settlements in 2002. and still belonged to the agrarian type, 129 or $48 \%$, but this is a significant decline compared to $96 \%$ in 1981 . In addition, 58 more settlements (22\%) had a mixed function with predominantly agrarian function: 34 agro-industrial and agrarian24 service. Significantly increased the number of settlements industrial-agrarian and industrial-type service, but also the settlement with primary service functions.

Fig. 4. shows that the generators changes in municipal centers and main roads in the district. Industrial and service activities are expanding from municipal centers in the suburbs, 
where people travel to municipal centers to carry out activities. In addition, some manufacturing and service facilities are moved to the hinterland cities to reduce costs or due to changes in the needs of the population now lives practically urban way of life and in the settlements. The main road route Niš-Priština is also a major generator of change, because it is noticeable that a large number of settlements along this road developed service functions, but now belong to the service or the principal or mixed types with predominantly service functions. In addition to these settlements, services are dominant and in spas (Prolom, Kuršumlijska and Lukovska). The most intensive changes have gone in the municipality Žitoradja, which largely gravitates to Niš, but the impact of this great town felt and settlement functions of the municipality (Spatial Plan of the Municipality of Žitoradja).

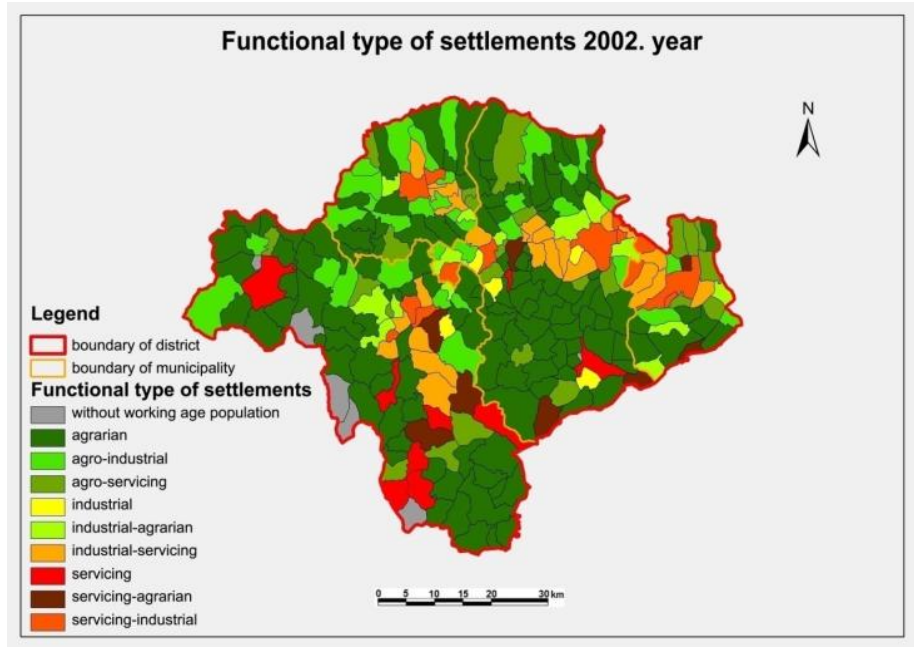

Figure 4. Functional type of settlement, 2002. (Republican Statistical Office of Serbia, 2002).

Demographic trends in Toplica are indicated by the fact that in 2002. there were 6 settlements without population performing occupation. Such settlements are mainly distributed along the administrative border with Kosovo and Metohija. Deagrarization process has continued during the period 2002-2011. to such an extent that more settlements with predominantly service function (98 or $36.7 \%$ - services 37,11 and 50 clerical agrarian-industrial service), but the village with predominantly agrarian function (92 or $34.5 \%$ - 50 agricultural, 19 agro-industrial and agrarian-23 service).

There is an evident increase in the number of industrial settlements, but the decline of the settlements of mixed-function type with periodical participation of the industrial sector. However, what is most disturbing is the increase in the number of settlements without population performing occupation. Such settlements in 2011. as many as 38 or $14 \%$ and are located in the higher parts of the municipality of Kuršumlija and Prokuplje.

On the Fig. 5. is noticeable that the municipal centers and the main road continues generators changes and land reclamation, as well as to form a kind of agglomeration Prokuplje-Žitoradja whose main characteristic domination of tertiary and quaternary activities.

If we look at the demographic and economic trends, it is expected that in the future period should be increasing number of settlements without population performing occupation and to reduce the number of settlements of agrarian function type. Secondary sector activities, primarily wood-processing industry, in the case of expansion could not keep a determined amount of population and the challenges of further diversification of the economy, because the strong industrial sector has caused the development of roadside service activities.

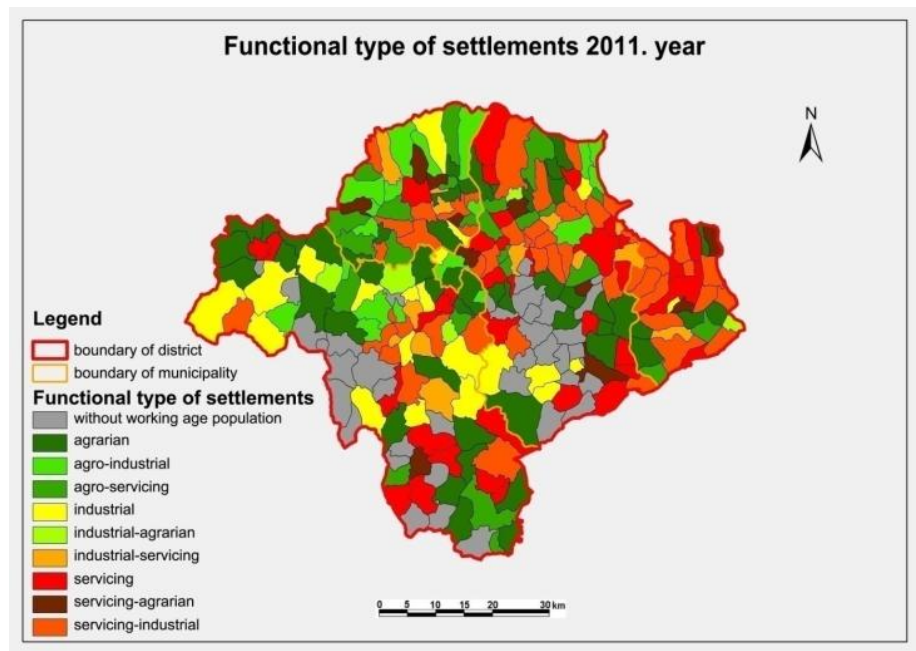

Figure 5. Functional type of settlement, 2011. (Republican Statistical Office of Serbia, 2012).

\section{CONCLUSION}

This paper presents a functional typology of Toplica District respectively Prokuplje, Kuršumlija, Blace and Žitoradja. In this area in the second half of the twentieth and early twentyfirst century witnessed substantial changes in almost all components of demographic structure, which resulted in the transformation of functional types of settlement, when the predominantly agrarian settlement characteristic of the area of Toplica road went up and mixed noagrarian settlements.

In the district of Toplica, 215 agricultural settlements had agrarian as a dominant or complementary function, of which more than half had a pure agrarian function. Settlements are located on the southern slopes of Jastrebac, in the north of the county, then the village located on the slopes of Kopaonik and Radan mountain and village on the slopes Pasjače and Vidojevica are not affected by functional transformation. Character of these settlements is still agrarian, with agriculture only source of income. Agrarian functions are dominant in the mountainous areas of the municipality. In fact, this mountain village are not holders of agricultural production, already the 
declared population as a farm used as a parameter in determining the functional typology of the village, according to the abovementioned methodology. The analysis of the network of settlements and the functional characteristics of the village, there is a phenomenon of rural settlements, the socalled secondary centers where they developed the tool much more than in their environment.

The development of this area should be carried out exactly according to the model microdeveloping nucleus, and these secondary centers. To achieve functional transformation of rural settlements, it is necessary to develop some functions in some of them which it will exert influence on their environment and to encourage its development. New industries should be located according to space and the population potentials, and not displace existing drives industry. It is very important to connect them with high-quality network of roads, among themselves as well with the municipal center. These secondary centers need to be evenly choosen and transfered to some of the functions and activities (administrative, educational, health), which would allow a public affirmation of the population and kept him in the country. Thus, to achieve the qualitative transformation space.

\section{REFERENCES}

Boudeville, J. 1966. Problems of Regional Planning.Edinburgh: Edinburgh University Press.

Christaller, W. 1933. Die Zentraleen Orte in Südeutschland. Eine ökonomischegeographische Untersuchung über die Gestmässigkeit der Verbreitung and Entwicklung der Siedlungen mit stadtischen Functionen.Darmstadt. DoktorDisertation (Gustav Fischer Jena). Reprinted 1980.

Davies, E.K.D. 1967. Centrality and the Central Place Hierarchy. Urban Studies, 4.
Dragojlović, J. 2017. The nodal centres of Toplica district.Belgrade: University of Belgrade - Faculty of Geography. Doctoral dissertation.

Federal Statistical Yugoslavia (SZS). 1984. Census, households and apartments in 1981.Belgrade. Table 194 and 195.

Grčić, M. 1999. Functional classification of the settlements Mačve, Šabačke Posavine i Pocerine. The messenger of the Serbian geographical society, notebook 1 .

Green, N. 2004. General Functional Polycentricity: A definition. Polinet-Working Paper.

Matijević, D. 2009. Spatial functional connection of the settlements Municipalities Stara Pazova with the urban sistem of Belgrade.Belgrade: Geographical institute Jovan Cvijic.

Myrdal, G. 1957. Economic Theory and Underdeveloped Regions.London: University Paperbacks, Methuen., pp. 1213.

Rudić, V. 1978. Population of Toplica.Belgrade: Belgrade Ethnographic Institute of SANU. Special edition, book 17.

Republican Statistical Office of Serbia (RZS). 2002. Census, households and dwellings in the Republic of Serbia in 2002. Belgrade. 3 .

Republican Statistical Office of Serbia (RZS). 2012. Census of Population, Households and Dwellings in the Republic of Serbia, 2011. Belgrade. 11.

Spatial plan of the Municipality of Blace.

Spatial Plan of the Municipality of Kuršumlija.

Spatial Plan of the Municipality of Prokuplje.

Spatial Plan of the Municipality of Žitoradja.

Stamenković, S., \& Bačević, M. 1992. Geography of the settlements, University textbook.Belgrade: University of Belgrade - Faculty of Geography - University of Belgrade Faculty of Science.

The regional spatial plan for the territory of Nišava, Toplica and Pirot District.

Tošić,D. 2012. Principles of regionalization.Belgrade: University of Belgrade - Faculty of Geography.

Vresk, M. 1990. A town in regional and urban planning.Zagreb: School books. 